UNITED STATES DEPARTMENT OF THE INTERIOR

GEOLOGICAL SURVEY

\title{
ORDOVICIAN-SILURIAN VOLCANOGENIC MASSIVE SULFIDE DEPOSITS \\ ON SOUTHERN PRINCE OF WALES ISLAND AND THE BARRIER ISLANDS, SOUTHEAS TERN ALASKA
}

by

George E. Gehrels, Henry C. Berg, and Jason B. Saleeby

This report is preliminary and has not been reviewed for conformity with Geological Survey editorial standards and stratigraphic nomenclature.

\author{
Menlo Park, California
}


INTRODUCTION

Several pyritic massive sulfide deposits have been recognized in an Ordovician-Silurian volcano-plutonic complex in the southern Prince of Wales Island region (Fig. 1). These deposits have been studied as part of a U.S. Geological Survey-California Institute of Technology investigation into the geologic and mineralization history of southern Prince of Wales Island (south of $55^{\circ}$ North Latitude; Fig. 1). This report describes the geologic setting of the deposits and presents preliminary chemical analyses of the mineralization.

\section{GEOLOGIC SETTING}

Southern Prince of Wales Island is underlain by pre-Middle Ordovician metamorphic rocks of the Wales Group, an Ordovician-Silurian complex of sedimentary, volcanic and plutonic rocks, Devonian clastic strata, and granitic plutons of probable Cretaceous age. The Ordovician-Silurian complex includes primarily dioritic to trondhjemitic plutons on the east side of the island, and interstratified marine sedimentary and intermediateto silicic-composition volcanic rocks to the west. Although Buddington and Chapin (1929) and Mackevett (1963) inferred that these sedimentary and volcanic rocks were a lower part of the Devonian section and that the plutonic rocks were Cretaceous in age, $\mathrm{K} / \mathrm{Ar}$ analyses of the plutonic rocks have subsequently yielded Ordovician-Silurian ages (Lanphere and others, 1964; Turner and others, 1977), and Ordovician conodonts and graptolites have been recovered from the marine strata (Eberlein and others, 1983).

The sedimentary and volcanic members in this complex are generally correlative with the Lower Ordovician-Lower Silurian Descon Formation on northwestern Prince of Wales Island (Eberlein and Churkin, 1970). The main difference in stratigraphy between these two areas is the presence of silicic volcanic rocks on southern Prince of Wales Island. In the study area these silicic volcanic rocks occur as flow and pyroclastic breccias that reach several hundred meters in thickness, and as 1 - to $3-m$-thick tuffs. These silicic volcanic rocks are interbedded with siliceous black slate, ferruginous dolomite and a fragmental, less-silicic volcanic rock that is generally the host for the massive sulfide deposits. The predominant volcanic rocks in the Ordovician-Silurian complex are andesitic to basaltic pillow flows, pillow breccia and pyroclastic breccia.

A regional unconformity separates the Ordovician-Silurian complex from overlying Devonian fluvial and marine clastic strata. This unconformity records Late Silurian-Early Devonian uplift and erosion, followed by deposition in subsiding basins during Early and Middle Devonian time (Gehrels and others, 1983).

Ordovician through Devonian rocks on southern Prince of Wales Island are juxtaposed against greenschist and amphibolite facies rocks of the Wales Group along a regional low-angle fault (Herreid and others, 1978; Redman, 1981). Although protoliths for the Wales Group metamorphic rocks were similar to lithologies in the Ordovician-Silurian sedimentary and volcanic complex, the Wales Group is readily distinguished by its penetrative syn-metamorphic flattening and stretching fabric, and post-metamorphic, 


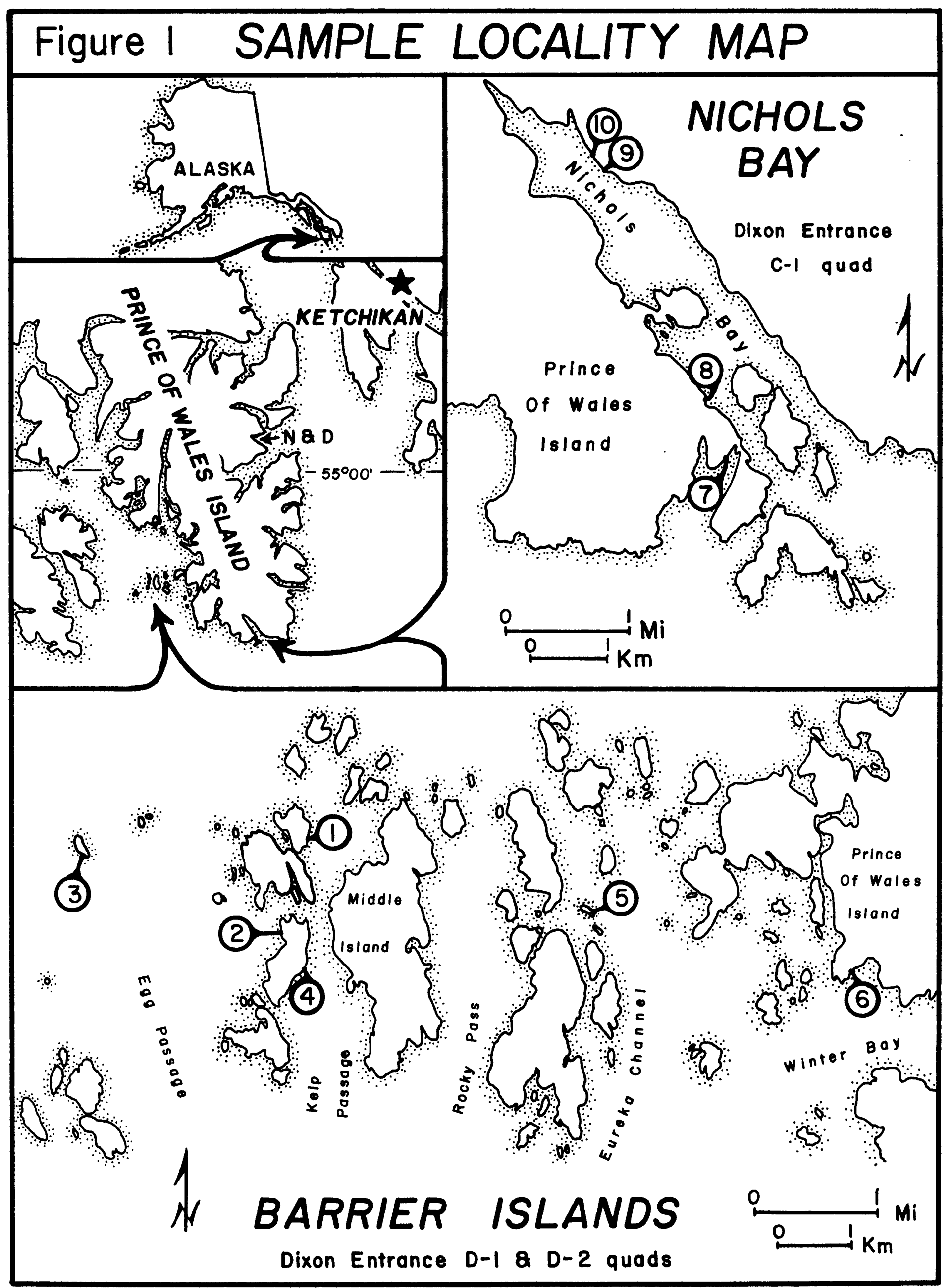


generally asymmetric folds. The primary relationship between the Wales Group and the Ordovician-Silurian rocks is not yet known, but a K/Ar isochron (Turner and others, 1977) and preliminary $\mathrm{U} / \mathrm{Pb}$ age data suggest that the main metamorphism and deformation in the Wales Group occurred about 475 million years ago. The Wales Group, the Ordovician through Devonian rocks, and locally the fault that separates them, are all intruded by granitic plutons of probable Cretaceous age (Herreid and others, 1978; Redman, 1981). We therefore infer that the thrust fault moved after Middle Devonian and prior to Cretaceous(?) time.

\section{DESCRIPTION OF THE DEPOSITS}

The massive sulfide deposits described in this report occur in the Barrier Islands, which is in the South Prince of Wales Wilderness, and in the Nichols Bay area of Prince of Wales Island (Fig. 1). In the Barrier Islands the deposits are associated with fragmental volcanic rocks that appear to have compositions between the intermediate and the silicic volcanic rocks. The composition of these fragmental volcanic host-rocks will be referred to as silicic-intermediate in this report. At several localities, the sulfide minerals occur in $<5-\mathrm{cm}-$ thick layers or rinds around 5- to 20-cm-1ong fragments in this silicic-intermediate volcanic rock. The elongate shape and interlocking nature of the fragments, combined with the presence of calcite-filled amygdules in the interior of the fragments, suggests that they may be flattened pillows. Massive sulfide minerals also form $<5-\mathrm{cm}$-thick layers in siliceous black slate and in silicic volcanic rocks.

In Nichols Bay the sulfide minerals occur as stratiform layers interbedded with quartz-rich graywacke and silicic volcanic rocks, and as thin layers and lenses in the volcanic rocks. Chapin (1918, p. 67) reports that several chalcopyrite-bearing prospects in the northeastern Nichols Bay area were worked in the ear1y 1900's.

The association of these sulfide deposits with the interlayered silicic volcanic and marine sedimentary rocks suggests that the deposits are of the syngenetic submarine volcanic (exhalative) type. Some deposits have subsequently undergone low-grade metamorphism that has resulted in variable amounts of remobilization or reconcentration of the sulfide and gangue minerals.

At each of the deposits, samples were collected from the most sulfiderich horizon, the same horizon where it lacked sulfides (for background), and any other sulfide-bearing or altered rocks. These samples were analyzed by S. Sutley and J.D. Hoffman of the U.S.G.S. using semiquantitative spectrographic and atomic absorption techniques. The geologic setting and mineralogy of the deposits is described briefly below, and the analytical data for the samples are given in Table 1.

$$
\text { BARRIER ISLANDS (Fig } \cdot 1 \text { ) }
$$

LOCALITY 1 (82ABg001) Island at the northwest end of Kelp Passage.

Sulfide minerals occur in interbedded silicic-intermediate pillowflows, pyroclastic breccia, and siliceous black slate. These units strike 
$\mathrm{N} 35^{\circ} \mathrm{W}$ and $\operatorname{dip} 80^{\circ} \mathrm{NE}$, and are bounded on the northeast and southwest by intermediate-composition pillow breccia and flows. Mineralized horizons outcrop discontinuous1y for about $300 \mathrm{~m}$ along shore and may continue along strike to the northwest side of the island where similar sulfidebearing rocks occur. The massive sulfides generally form $1-$ to $6-\mathrm{cm}-$ thick rinds around the pillows, or occur as thin layers or pods in both the volcanic and sedimentary rocks.

1A: Massive pyrite and possibly arsenopyrite ${ }^{1}$ in thin, discontinuous layers that are paralle1 to bedding in a quartz-rich sedimentary rock. The mineralized rock is a $2 \mathrm{~m}$ by $3 \mathrm{~m}$ lens enclosed in pillow breccia near the north end of the zone of mineralization.

1B: Pyrite-rich silicic-intermediate fragmental volcanic rock that forms a prominent $3 \mathrm{~m}$ by $10 \mathrm{~m}$ rusty weathering horizon near the north end of the mineralized zone. The fragments have calcite amygdules and a calcite-rich, tuffaceous(?) matrix, and are inferred to be pillow-breccia fragments.

1C: Massive pyrite and possibly arsenopyrite ${ }^{1}$ that forms layers or rinds up to $6 \mathrm{~cm}$ thick around pillows. These rinds occur in a 1-m-wide by 10-m-1ong horizon that is parallel to the strike of the layering and a flattening of the pillows.

1D: Disseminated pyrite and possibly arsenopyrite ${ }^{l}$ in a fairly massive rusty weathering layer adjacent to the pillows sampled at $1 \mathrm{C}$.

$1 \mathrm{E}:$ Interior of the pillow sampled at 1C. The pillows are generally about $10 \mathrm{~cm}$ long, slightly flattened, and have calcite-filled amygdules. Pyrite is sparsely disseminated throughout the pillows.

1F: Thin, discontinuous layers of massive pyrite in a laminated dark gray slate near the southeast tip of the island. The slate is a 3-m-wide interbed within the volcanic rocks.

1G: Massive pyrite (accompanied by microscopic traces of sphalerite) from the most prominent rusty weathering horizon at the south end of the zone of mineralization. The sulfides generally occur in layers up to $5 \mathrm{~cm}$ thick in a folded and deformed silicic-intermediate fragmental volcanic rock.

LOCALITY 2 (82ABg002) - Northwest side of the central island between Ke1p and Egg Passages.

Sulfide minerals occur along this shoreline in a 5 -m-thick by $50-m-$ long rusty weathering layer of silicic-intermediate volcanic rocks. The mineralized volcanic rocks are bounded on the west by a massive silicic flow and on the east by intermediate-composition pillow breccia and tuffaceous agglomerate. Layering and a faint foliation are oriented $\mathrm{N} 18^{\circ} \mathrm{W}, 80^{\circ} \mathrm{NE}$, and project south-southeast across the island to locality 4 where similar sulfide-bearing rocks are present. Thus, the strike length of the mineralized zone may be at least $700 \mathrm{~m}$. Massive sulfide minerals at the north end of the mineralized layer occur as 2- to 4-cm-thick rinds around slightly flattened pillow-1ike fragments.

1

Spectrographic analysis (Table 1) indicates that arsenopyrite is present. 
2A: Massive fine-grained pyrite and arsenopyrite 1 form a 2- to 5-cm-thick layer that is parallel to the compositional layering. Alteration of this layer produces a prominent rusty weathering horizon.

2B: Disseminated pyrite and arsenopyrite 1 that forms up to $40 \%$ of a highly altered, yellow-orange weathering zone adjacent to the main massive sulfide layer (sample 2A). The foliated volcanic host-rock is rich in carbonate.

2C: Silicic-intermediate volcanic rock adjacent to the main sulfide-rich layer (sample 2A). The volcanic rock has angular pyroclastic(?) fragments in a carbonate-rich matrix, and contains sparsely disseminated pyrite.

2D: Silicic volcanic rock with sparsely disseminated pyrite and probably sphalerite ${ }^{2}$ on the west side of the mineralized layer.

LOCALITY 3 (82ABg003) - Small island in the northwestern Barrier Islands.

Massive sulfide minerals occur in a silicic-intermediate volcanic rock interbedded with intermediate-composition flows. Mineralization occurs in a $N 54^{\circ} \mathrm{W}, 75^{\circ} \mathrm{NE}$ zone that is $5 \mathrm{~m}$ wide and at least $30 \mathrm{~m}$ long: a NlOW, vertical fault truncates the northern end of the exposure. The sulfide minerals form well-developed pyrite-rich rinds around pillows or pillow fragments.

3A: Pyrite accompanied by microscopic traces of sphalerite and possibly arsenopyrite 1 in rinds around pillows. The rinds are 2 to $5 \mathrm{~cm}$ thick and consist of massive and disseminated sulfide minerals in a quartzand carbonate-rich matrix.

3B: Sulfide-poor core of the pillow sampled at $3 \mathrm{~A}$.

LOCALITY 4 (82ABg004) - West side of Kelp Passage.

Disseminated and massive sulfides occur in a silicic volcanic breccia which is interlayered with dark gray slate, ferruginous dolomite, and intermediate-composition flows and tuff. The silicic breccia has finely laminated angular fragments in a matrix of similar composition, and is inferred to be a pyroclastic breccia. The sulfide minerals occur as thin layers and lenses in a 1-m-wide by $10-\mathrm{m}-1$ long zone in the volcanic rocks. This mineralized horizon may be continuous with the deposit at locality 2 , about $700 \mathrm{~m}$ to the north-northwest.

4A: Sparsely disseminated pyrite in the silicic breccia.

4B: Massive pyrite and a trace of arsenopyrite in a 1- to 5-cm-thick layer in the breccia. This layer is parallel to compositional layering and a faint flattening of the fragments.

4C: Ochre-weathering ferruginous dolomite. The dolomite forms a 1 -m-wide layer of recrystallized fine-grained carbonate that was probably a limestone interbed within the volcanic rocks.

1 2 Spectrographic analysis (Table 1) indicates that arsenopyrite is present. Spectrographic analysis (Table 1) indicates that sphalerite is present. 
LOCALITY 5 (82ABg005) - Sma11 island in the northwest part of Eureka Channe1.

A sheared contact zone between quartz diorite to the south and silicic- to intermediate-composition volcanic rocks to the north is exposed on this island. The sulfide minerals occur as thin discontinuous layers in a sliver of silicic pyroclastic(?) breccia within this shear zone. J. Saleeby suggests that the silicic breccia may be a syn-volcanic intrusive along this shear zone, rather than an extrusive breccia.

5A: Discontinuous pyrite-rich layers that occur in a meter-wide zone in the silicic volcanic rock.

5B: Pyrite-bearing, rusty weathering volcanic rock. Spectrographic analysis (Table 1) indicates that arsenopyrite is present.

LOCALITY 6 (82ABg006) - Northwest shore of Winter Bay, eastern Barrier Islands.

A severa1-hundred-m-wide zone of variab1y mineralized dark gray slate and silicic volcanic breccia and tuff crops out along the north shore of Winter Bay. Disseminated pyrite is present in most of the section, and small pyrite-rich stringers occur in both the volcanic and sedimentary rocks. Several of these stringers form prominent rusty weathering exposures along the shoreline. The beds dip steeply and strike at a high angle to the shoreline, so the length of the mineralized zone is not known.

6A: Pyrite-rich pyroclastic breccia composed of 2- to 4-cm angular fragments in a matrix of similar composition.

6B: Sulfide-poor breccia adjacent to sulfide-rich zone at $6 \mathrm{~A}$.

6C: Rusty weathering gray-black slate that contains disseminated pyrite. The slate is a 1 -m-thick interbed within the volcanic breccia.

$$
\text { NICHOLS BAY AREA (Fig • 1) }
$$

LOCALITY 7 (82ABg 007) - South end of Nicho1s Bay.

Massive sulfides at this locality form 2- to 6-cm-thick lenses and discontinuous layers in a locally fragmental silicic volcanic rock. The zone that contains these layers is about $6 \mathrm{~m}$ wide, and forms a linear topographic depression along strike to the north-northwest. The mineralized volcanic rock is interbedded with intermediate-composition pillow breccia and massive flows. We suspect that the host-rock is a fragmental flow or pyroclastic breccia, although it could be a hypabyssal intrusive. Intermediatecomposition dikes cut the mineralized zone.

7A: Medium-grained pyrite that forms up to $60 \%$ of a $2-$ to 6 -cm thick layer within the silicic volcanic rock. The pyrite is accompanied by microscopic traces of sphalerite.

7B: Thin, pyrite-rich layer in the volcanic rocks. Microscopic traces of sphalerite are also present. 
7C: Sulfide-poor silicic volcanic rock adjacent to the more sulfide-rich layer at $7 \mathrm{~A}$.

LOCALITY 8 (82ABg008) - Southern Nichols Bay.

Massive sulfides occur primarily as several-cm-thick layers in a fragmental silicic volcanic rock at this locality. Disseminated pyrite is also present in intermediate-composition flows with which the mineralized rocks are interbedded, and in a quartz-feldspar porphyry that intrudes the volcanic rocks. The massive sulfide is confined to a 10-m-wide zone that may be continuous with the occurrence at locality 7 .

8A: 2- to 4-cm-thick layer of massive pyrite, accompanied by microscopic traces of sphalerite, in a highly altered, carbonate-rich silicic volcanic rock. Alteration from this layer forms a prominent rusty weathering zone.

8B: Disseminated pyrite in a massive volcanic rock adjacent to $8 \mathrm{~A}$.

8C: Disseminated pyrite in the quartz-feldspar porphyry intrusive.

LOCALITY 9 (82ABg009) - Northeast shore of Nichols Bay.

Several massive-sulfide-bearing layers occur in a sequence of interbedded graywacke, slate, and silicic volcanic rocks along the northeast shore of Nichols Bay. The main occurrence at this locality is a 3-m-wide layer in which massive pyrite and sphalerite form several-cm-thick layers that are similar to those in the surrounding graywacke. These sedimentary rocks are interbedded with silicic volcanic rocks and gray-black slate -both of which contain disseminated pyrite and thin layers of massive sulfides. The sulfide-bearing horizons are generally parallel to $N 8^{\circ} \mathrm{E}, 75^{\circ} \mathrm{SE}$ bedding in the host rocks. An old shaft is present in the main massive sulfide layer, and Chapin (1918, p. 67) describes other prospects in this sequence of rocks in the northeastern part of Nichols Bay. Chapin described copper as the valuable metal in these deposits, but our analyses (Table 1) show that they also contain possibly significant amounts of zinc and silver. Little apparent work has been done on any of these prospects since they were visited by Chapin, although claims have been staked in the last decade. Samples were collected along a 12-m-1ong shoreline traverse across the main lode and adjoining sedimentary and volcanic rocks. Samples 9A through 9I are located from north to south along this traverse.

9A: Sparsely disseminated pyrite in silicic volcanic rock that crops out nearly continuously along the shoreline to locality 10.

9B: Disseminated pyrite and arsenopyrite 1 in a silicic volcanic rock adjacent to $9 \mathrm{~A}$.

9C: 1-m-wide pyrite- and sphalerite-bearing layer in the volcanic rocks.

9D: Layer of massive pyrite and disseminated sphalerite and arsenopyrite ${ }^{1}$ in a rusty weathering layer adjacent to $9 \mathrm{C}$. 
9E: Disseminated pyrite, sphalerite and arsenopyrite ${ }^{1}$ in .quartz-rich graywacke adjacent to the main lode.

9F,G, and H: Massive sulfides collected from different parts of the main lode. Pyrite and subordinate sphalerite and arsenopyrite ${ }^{1}$ constitute about $90 \%$ of 1- to 3-cm-thick layers that are interbedded with thinner, quartz-rich layers.

9I: Fine-grained pyrite and arsenopyrite ${ }^{1}$ disseminated through banded graywacke on the south side of the main lode.

LOCALITY 10 (82ABg010) - Northeast shore of Nichols Bay, $500 \mathrm{~m}$ north of locality 9 .

Silicic volcanic rocks occur along this shore from locality 9 to at least a kilometer north of this locality. Discontinuous zones of disseminated and massive sulfides in these rocks may be similar to the mineralized zones at the Feickert claim described by Chapin (1918, p. 67).

10A: Disseminated pyrite and arsenopyrite ${ }^{1}$, accompanied by microscopic traces of sphalerite, in rusty weathering, foliated, silicic volcanic rock.

10B: Disseminated pyrite in foliated silicic volcanic rock.

\section{DISCUSSION}

Field relationships and various age constraints suggest that the massive sulfide occurrences on southern Prince of Wales Island and the Barrier Islands are syngenetic mineral deposits in an Ordovician-Silurian volcano-plutonic complex. A similar origin has been proposed for some of the iron-copper deposits in Upper Ordovician-Lower Silurian andesitic volcanic rocks on east-central Prince of Wales Island (Eberlein and Churkin, 1976, p. 89).

Similar types of massive sulfide deposits have yielded significant quantities of copper from the Niblack Mine and the Dama Prospect ("N \& D" on Fig. 1; Herreid, 1964), and occur at many other localities on south-central Prince of Wales Island (Herreid and others, 1978, Table 5). The metavolcanic and metasedimentary host-rocks at these mines and prospects, however, are thought to be part of the Wales Group rather than the OrdovicianSilurian complex (Eberlein and others, 1983; Redman, 1981, Fig. 1) - Because the primary relationship between the Wales Group and the Ordovician-Silurian rocks is poorly constrained, we do not yet know whether the mineral deposits in the two packages of rocks are genetically related. Mapping and $\mathrm{U} / \mathrm{Pb}$ geochronologic studies in progress may help discern the differences in geologic and mineralization history between these two assemblages. In either case, the massive sulfide deposits within the Ordovician-Silurian rocks in the southern Prince of Wales Island region appear to warrant additional investigation.

\section{ACKNOWLDGEMENTS}

We thank Jim Hoffman and Stephen Sutley of the U.S.G.S. for quick1y completing the chemical analyses of these samples. 


\section{REFERENCES}

Buddington, A.F., and Chapin, Theodore, 1929, Geology and mineral deposits of southeastern Alaska: U.S. Geological Survey Bulletin 800, 398 p.

Chapin, Theodore, 1918, Mining developments in the Ketchikan and Wrange11 mining districts, 1916: U.S. Geological Survey Bulletin 662, p. 63-75.

Eberlein, G.D., and Churkin, Michae1, Jr., 1970, Paleozoic stratigraphy in the northwest coastal area of Prince of Wales Island: U.S. Geological Survey Bulletin 1284, 67 p.

Eberlein, G.D., and Churkin, Michae1, Jr., 1976, Ear1y Paleozoic volcanic center and associated iron-copper deposits, in Geological Survey Research 1976: U.S. Geological Survey Professional Paper 1000, p. 89.

Eberlein, G.D., Churkin, Michae1, Jr., Carter, Claire, Berg, H.C., and Ovenshine, A.T., 1983, Geology of the Craig quadrangle, Alaska: U.S. Geologica1 Survey Open-File Report 83-91.

Gehre1s, G.E., Saleeby, J.B., and Berg, H.C., 1983, Preliminary description of the Late Silurian-Early Devonian Klakas orogeny in the southern Alexander Terrane, southeastern Alaska, in Stephens, C., ed., Paleozoic and Early Mesozoic Rocks in Microplates in Western North America: Pacific Section, Society of Economic Paleontologists and Mineralogists, Pacific Coast Paleogeography Symposium, in press.

Herreid, Gordon, 1964, Geology of the Niblack Anchorage area, southeastern Alaska: Alaska Division of Mines and Minerals Geologic Report No. 5, 10 p.

Herreid, Gordon, Bundtsen, T.K., and Turner, D.L., 1978, Geology and geochemistry of the Craig A-2 quadrangle and vicinity, Prince of Wales Island, southeastern Alaska: Alaska Division of Geological and Geophysical Surveys Geologic Report $48,49 \mathrm{p}$.

Lanphere, M.A., MacKevett, E.M. Jr., and Stern, T.W., 1964, Potassium-argon and Lead-alpha ages of p1utonic rocks, Bokan Mountain area, Alaska: Science, v. 145 , no. 3633 , p. 705-707.

MacKevett, E.M., 1963, Geology and ore deposits of the Bokan Mountain UraniumThorium area, southeastern Alaska: U.S. Geological Survey Bulletin 1154, 125 p.

Redman, Ear1, 1981, The Keete Inlet thrust fau1t, Prince of Wales Island: Alaska Division of Geological and Geophysical Surveys, Accomplishments during 1981, p. 17-18.

Turner, D.L., Herreid, Gordon, and Bundtzen, T.K., 1977, Geochronology of southern Prince of Wales Island, Alaska, in Short Notes on Alaskan Geology: Alaska Division of Geology and Geophysical Surveys Geological Report 55, p. 11-16. 


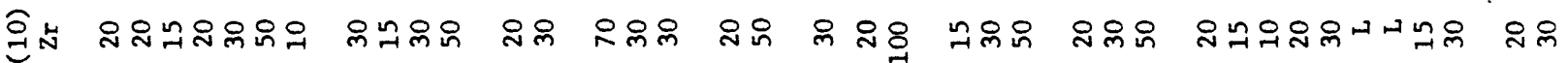

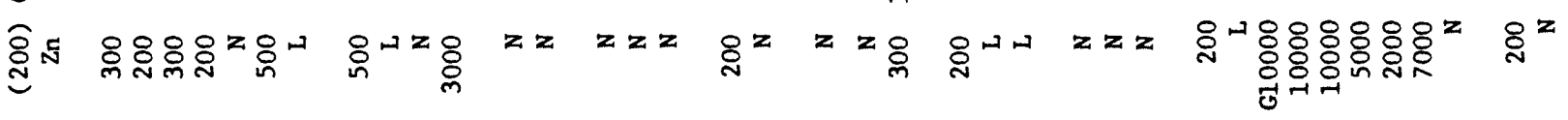

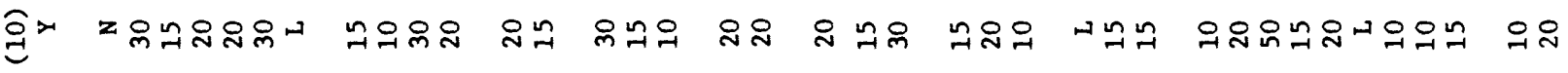

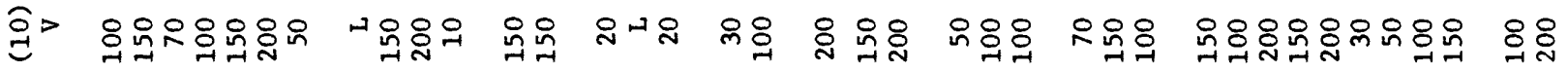

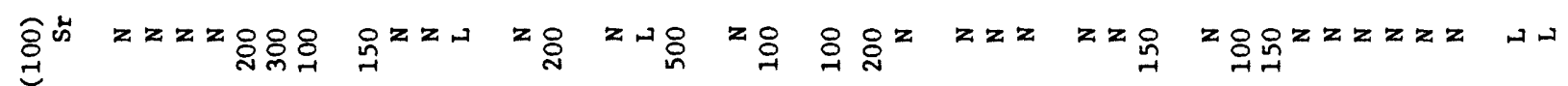

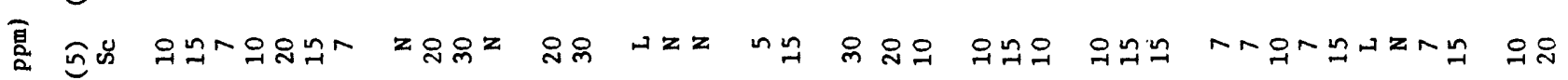

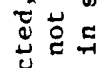

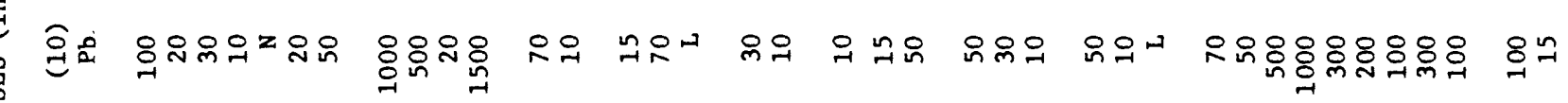

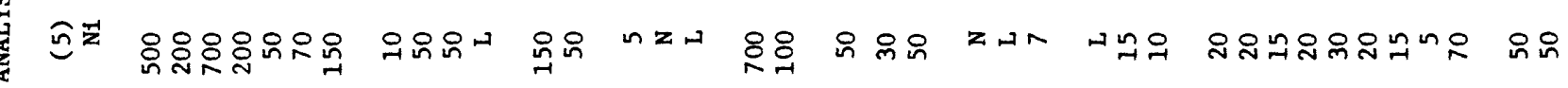

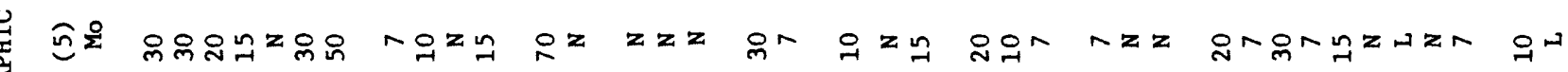

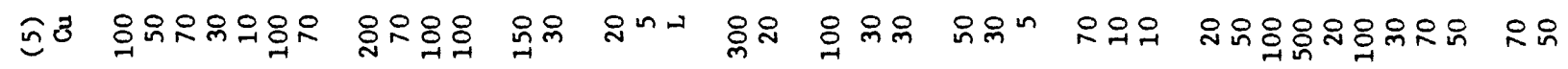

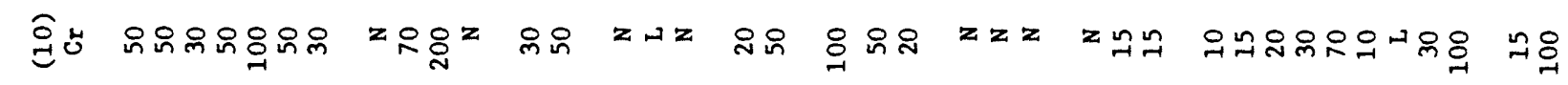

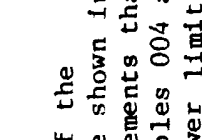

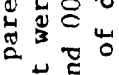
政

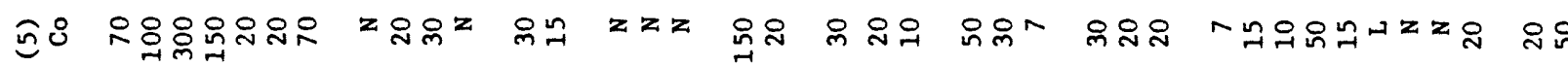

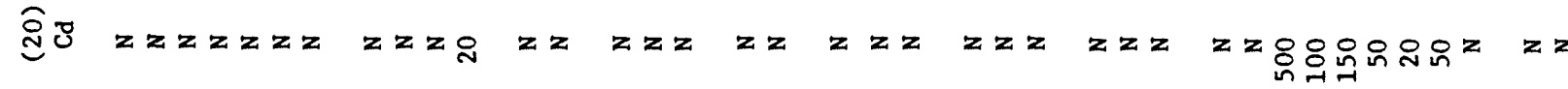

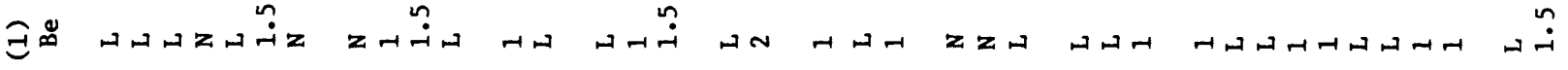

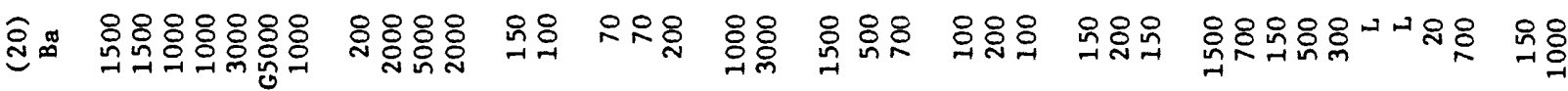

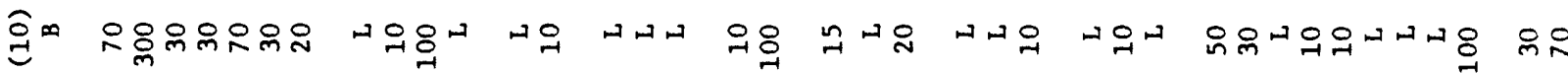

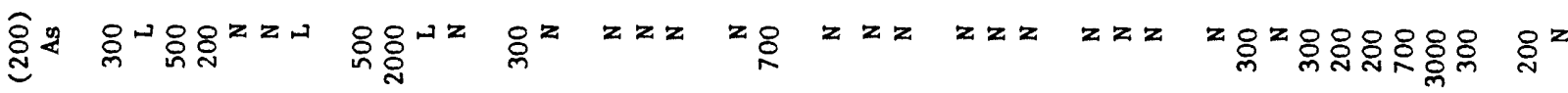

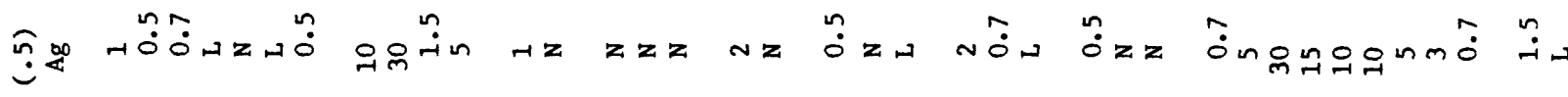

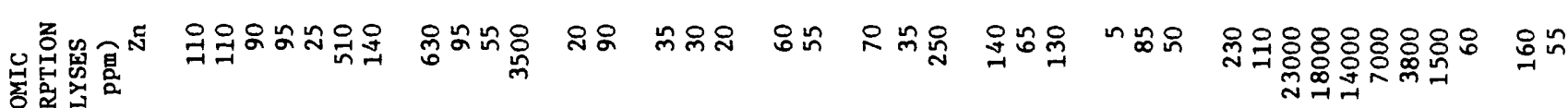

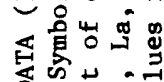

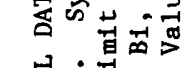

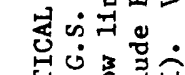

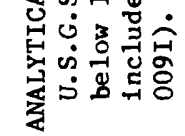

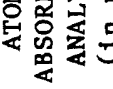

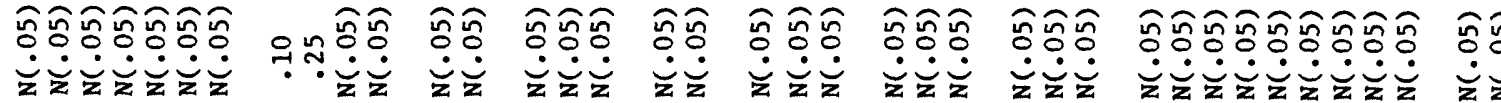

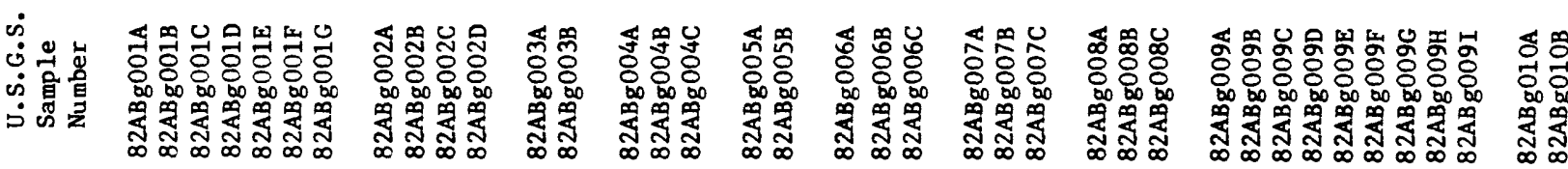

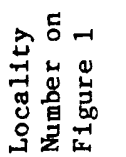

